\title{
Movement of the components of Russian financial capital
}

\author{
Valery Smirnov, Denis Osipov*, Elena Lyubovtseva, Elvira Kuznetsova, and Ludmila \\ Savinova \\ Chuvash State University, Cheboksary, Russia
}

\begin{abstract}
In the article there is revealed movement of financial capital components as a substance - the unity of diversity and the diversity of unity. Analysis of USD / RUB, RGBI, RTSI, SBER, IMOEX dynamics revealed speculative behavior of financial capital owners (IMOEX, USD / RUB, SBER) in relation to internal (RGBI) and external (RTSI) market. Analysis of importance of growth rates of GDP and its components revealed the state priority of GDP deflator regulation (Central Bank - inflation targeting) in the context of state revenues growth and, as a structural consequence, reduction of importance of growth rates of GDP and expenditures of households consumption against the background of increase of importance of commodities and services import. At the same time the quite high values of importance of growth rates of export of Russian commodities and services are identical to ones of such countries as Australia, Estonia and Columbia. Analysis of capital growth rates revealed fixation of interrelations between the Central Bank and financial corporations in the context of regulation of money supply and currency outside financial corporations and internal claims. These relations strengthen due to focusing of monetary and credit policy at "clear requirements to central government" and at inflation targeting. Research of the Russian financial capital components movement demonstrated corporate strengthening of interrelations between the Central Bank and the financial corporations and also defined the options for regulation of speculative behavior of financial capital owners.
\end{abstract}

\section{Introduction}

Financial capital is the capital that was formed as a result of industrial and bank monopolies merger. During imperialism the process of concentration of production and capital leads to formation of monopolies that capture basic resources of society, use their economic and political dominance to intensify exploitation of the proletariat, for enrichment at the cost of millions of regular producers of commodities from the town and the village, to establish their control over multitude of small and medium entrepreneurs in order to gain monopoly-high profit.

First of all the monopolies capture internal market and the economy of home country in general. Progress of this process leads to formation of monopolies so huge that they hold in

\footnotetext{
* Corresponding author: $\underline{\text { denps @ mail.ru }}$
} 
their hands a significant share of global production of a whole industry. Emerging of such monopolies on a global market is accompanied with hard competition between them. In order to avoid losses they often make an agreement about separation of global markets of sales, raw materials and capitals, about establishment of monopoly prices and about joint use of methods maximizing their profits. There form international monopolies that carry out economic carving of the world and dictate a policy of new and new imperialist takeovers to their governments.

Militarism rises greatly during an imperialism period. Only military industry has a guaranteed state sales market not depending on any disturbances of capitalist reproduction process. Military industry has become an industry that defines development of capitalist economy to a significant degree.

Modern definition of a notion of financial capital connects bank capital (so as capital of non-bank credit and financial institutions) with industrial capital so that banks become not just financial mediators but large investors and they control cash flows of industrial companies. Financial capital is also considered as a resource of economic life that consists of financial (monetary documents, cash and non-cash resources) and real capital (resources invested to foreign economic activity).

Determination and assessment of financial capital components movement in modern economy becomes the cardinal objective for almost all countries.

Isaiah Oino demonstrated that banks diversified their income flows compared to the period prior to 2008. In terms of efficiency the ratio between costs and income after 2008 is higher than before the financial crisis [1].

Mirzaei Ali, Aguir Iness found out that despite capital flow brings a number of benefits to countries that receive it, but it might also aggravate some risks including financial instability. After the 2010-2014 crisis the financial stability of banks of developing countries reduced mostly due to foreign capital in the form of portfolio and/or credit investments. They emphasize the destructive role of financial crises that don't let developing countries to take advantage of financial stability brought by cross-border flows [2].

However, Haizhen Yang, Fangfang Shi, Jie Wang, Zhongbo Jing revealed that liberalization may finally cause escape of capital in portfolio streams in countries with developing economies [3].

Rogelio Mercado Jr., Shanty Noviantie distinguish different importance of global and internal factors of recognition of an economy's central position and of its chances to become a financial center. Importance of global credit and internal financial depth implies the importance of financial regulation and supervision alongside with financial deepening and development in provision of financial centers financial stability [4]. Emiliano Brancaccio, Raffaele Giammetti, Milena Lopreite, Michelangelo Puliga revealed a global tendency to growth and centralization of capital [5].

Kevin P. Gallagher, Yuan Tian demonstrated that after the financial crisis the International Monetary Fund started showing public support of what is traditionally called "capital control". The degree of capital control measures support by the IMF raised due to crisis and increased vulnerability related to capital flows [6].

Margarita Rubio, Fang Yao believe that the current environment of low interest rates creates new problems for the international bank regulation policy. On one hand, low interest rates lead to bank capital growth which requires less strict international control regimes. On the other hand, such an environment aids increasing of loaners debt requiring stricter regulation for macroprudential purposes. Analysis of countercyclical buffer in Basel III regulations shows that risks for financial stability outbalance the additional accumulation of bank capital [7]. 
Roman Matousek, Ekaterini Panopoulou, Andromachi Papachristopoulou used the global economic policy uncertainty index to show that the policy uncertainty increase leads to increase of capital dificit in the future in case of a serious market downturn [8].

Kyriaki Kosmidou, Dimitrios Kousenidis, Anestis Ladas, Christos Negkakis believe that financial statements quality measured by higher conditional conservatism and low level of profit management affects liquidity in a favorable way. However, during a capital control period the relation between conditional conservatism and liquidity becomes negative and that negative relation belongs to less risky companies [9].

Hengjie Ai, Kai Li, Fang Yang determined that adverse shocks of agents conflicts aggravate the irrational use of capital and manifestate as variations in the overall factor productivity at the aggregated level [10].

Alexandre Ripamonti discovered that reliability of various figures of target structure of capital and methods of dynamic panel data which lies in correspondence of the dynamic theory of compromise with the expectation of financial decisions of financial institutions [11]. Zachary Feinstein discovered the existence and unique nature of a joint system of behavior of a company and assets prices [12].

Byung-Uk Chong, Heonsoo Kim revealed that profitability of shares of a company with high volatility of capital structure that belong to groups of various size changes through time. This is an evidence of a capital structure volatility factor. Interrelation between capital structure volatility and shares profitability is also negative [13].

Sandip Dhole, Sagarika Mishra, Ananda Mohan Pal believe that the negative relation between financial restrictions and the future price of shares grows significantly weaker for the companies featuring effective management of current capital assuming that such companies have higher market value despite the financial restrictions [14].

Dongyang Zhang revealed that companies that got export tax rebates (ETR) are more likely to gain leverage access. Besides that, ETR: (1) affect the leverage ratio through funding of investments in the fixed assets, smoothening of financial expenditures and reduction of internal funding; (2) positively related to leverage due to improvement of company performance indices including the overall factor productivity, profitability and labor productivity. ETR influence on leverage also plays a more significant role in private companies than in state-owned or foreign companies [15].

Costas Lambrinoudakis, George Skiadopoulos, Konstantinos Gkionis revealed that expectations of future shocks explain the majority of standard factors defining leverage and greatly affect small and financially restricted companies [16]. Ouarda Merrouche, Erlend Nier determined that in anticipation of the global financial crisis in the developed economy countries there occurred imbalances as crediting was growing and obtaining more and more funding from wholesale financial markets [17].

Roberto Pancrazi, Hernán D. Seoane, Marija Vukotic claim that the capital price is the key factor defining a financial booster, a mechanism of translation of shocks occurring during accumulation of capital by entrepreneurs that experience difficulties when borrowing at loan markets [18].

Oscar Valencia, Daniel Osorio, Pablo Garay point out that without requirements to capital any shock reducing deposits interest rate would stimulate a bank to switch from bank capital to deposits thus increasing the demand for deposits and softening the shock effect on interest rates and mortgage loan prices. Requirements to capital amplify the reaction of aggregated variables to shocks at the cost of the right part of bank balance [19].

Christina Bui, Harald Scheule, Eliza Wu believe that moderate increase of bank capital buffers is sufficient to support financial system stability including economic downturns. Besides that, despite banks take advantage of paying lower cost of debt when they have higher buffer of capital, the volumes of crediting turn lower which indicates that offering loans might by hampered if bank capital levels are too high within the financial system [20]. 
Thus, movement of financial capital components in modern economy manifestates as a substance - the integrity of accidents, the unity of diversity and the diversity of unity capable of self-generation, self-support and self-development.

\section{Methods}

For the purpose of the Russian financial capital components movement analysis we use the methods of statistical, neural and cluster analysis including processing of statistical figures, their systematizing and representation in the form of diagrams and tables. Statistical data processing is done using IBM SPSS Statistics, while tables, diagrams and graphs were done in IBM SPSS Statistics and MS Excel.

Statistical analysis if a method of acquisition, studying and representation of large volumes of data by signs and interrelations of data, correlation interrelations of spatial and time rows of values observing the research methodology [21, 22].

Neural network analysis allows to determine the laws of changes of objects (phenomena) by building neural networks. This manifestates in establishment of significant relations of the Russian financial capital components dynamics and in determination of the basis of its existence.

Application of cluster analysis is determined by complementation of the probability understanding of casuality with the relatedness of changes of the assessed figures. Cluster analysis systematizes the data containing information about sampling of objects and arranges the research objects in comparatively homogenous groups. This allows to develop qualification of studied objects or phenomena, to determine the main patterns of their grouping and to formulate hypotheses [23].

Hypotheses formulated using the neural network and cluster analysis would allow to assess movement of the Russian financial capital components and to determine the options of financial market regulation.

\section{Results and Discussion}

Information basis for analysis of the Russian financial capital components movement is the data of the International Monetary Fund (IMF), the Central Bank of Russia, the Federal service for State Statistics of the Russian Federation, Intercontinental Exchange (TradingView), etc.

Analysis of USD / RUB, RGBI, RTSI, SBER, IMOEX dynamics (Figure 1) revealed two periods of "zeroing": March - April 2013 and February - March 2020 with consequent similar movement of financial market indicators (financial capital components). This dynamics shows that through the 2020 the financial capital passed the stage of significant change comparable to the period from March 2013 to March 2020 - USD / RUB (by 9.48 times), RGBI (by 3.9 times), RTSI (by 3.74 times), SBER (by 9.02 times), IMOEX (by 10.01 times). Dynamics of USD / RUB, RGBI, RTSI, SBER, IMOEX reflects speculative behavior of financial capital owners (IMOEX, USD / RUB, SBER) in relation to internal (RGBI) and external (RTSI) market.

Neural network analysis of importance of growth rates of GDP and its components revealed three main structural configurations (Table 1): (1) gross accumulation of fixed capital - 100\%, GDP - 52.5\%; (2) GDP deflator - 100\%, GDP - 18.1\%; (3) change of stock $-100 \%$; GDP $-2.8 \%$. In general the first structural configuration is the most reasonable in the context of the Russian economy development (growth rates of GDP, household consumption expenditures including non-profit institutions serving households, change of stock) but significantly reduces state and consumer expenditures. 
Table 1. Neural network analysis of the importance of GDP rates of gain and its components, 2004 2019.

\begin{tabular}{|c|c|c|c|}
\hline Rated value, RUB & \multicolumn{3}{|c|}{ Importance, \% } \\
\hline GDP & 52.5 & 18.1 & 2.8 \\
\hline $\begin{array}{c}\text { Households consumption expenditures, including non-profit } \\
\text { institutes serving households }\end{array}$ & 84.8 & 49.0 & 81.3 \\
\hline Government consumption expenditures & 3.0 & 19.0 & 16.7 \\
\hline Gross accumulation of fixed capital & 100.0 & 30.2 & 30.6 \\
\hline Change of stock & 13.9 & 68.3 & 100.0 \\
\hline Export of commodities and services & 2.2 & 35.9 & 48.7 \\
\hline Import of commodities and services & 35.3 & 50.5 & 11.3 \\
\hline GDP deflator & 15.4 & 100.0 & 37.8 \\
\hline
\end{tabular}

Note. Multilayer perception, batch training.

Source: calculated using "IBM SPSS Statistics" according to Rosstat, the The International Monetary Fund (IMF). https://data.imf.org.

Thus neural network analysis of importance of growth rates of GDP and its components revealed the state priority of GDP deflator regulation (Central Bank - inflation targeting) in the context of state revenues growth and, as a structural consequence, reduction of importance of growth rates of GDP and expenditures of households consumption against the background of increase of importance of commodities and services import. At the same time the quite high values of importance of growth rates of export of commodities and services are identical to ones of such countries as Australia, Estonia and Columbia (Table 2).

Table 2. Cluster analysis of the identity of the export rates of gain of the Russian Federation with the countries of the world, 2018M01-2020M04.

\begin{tabular}{|c|c|c|}
\hline \multirow{4}{*}{ Cluster } & Square of the Euclidean distance < 50000 \\
\hline Russian Federation & Australia & 411.910 \\
\cline { 2 - 3 } & Estonia & 842.821 \\
\cline { 2 - 3 } & Columbia & 1083.668 \\
\cline { 2 - 3 } & New Zealand & 1471.213 \\
\cline { 2 - 3 } & Japan & 1643.496 \\
\cline { 2 - 3 } & Latvia & 1913.563 \\
\cline { 2 - 3 } & India & 2044.981 \\
\cline { 2 - 3 } & Israel & 2306.819 \\
\cline { 2 - 3 } & Albania & 2367.901 \\
\cline { 2 - 3 } & Austria & 2678.035 \\
\cline { 2 - 3 } & Angola & 3195.977 \\
\cline { 2 - 3 } & Eswatini & 3453.712 \\
\cline { 2 - 3 } & China, PRC: Macao & 3835.328 \\
\cline { 2 - 3 } & Belarus & 4227.208 \\
\cline { 2 - 3 } & Sri Lanka & 4268.589 \\
\cline { 2 - 3 } & China, PRC: Hong Kong & 4492.561 \\
\hline
\end{tabular}

Note: Hierarchical cluster analysis - the average distance between clusters, the square of the Euclidean distance.

Source: calculated using "IBM SPSS Statistics" according to Rosstat, the The International Monetary Fund (IMF). https://data.imf.org.

Analysis of capital growth rates in the context of the Central Bank, financial corporations and trade revealed the maximum values:

- medians (Me): Central Bank / Other liabilities to deposit corporations; Financial corporations / Clear requirements to the central government; Trade / Commodities, cost of import;

- Average: Central Bank / Other liabilities to deposit corporations; Financial corporations / Clear requirements to the central government; Trade / Commodities, cost of import; 
- absolute difference between median and average value (ABS(Me-Average)): Central Bank / Other liabilities to deposit corporations; Financial corporations / Clear requirements to the central government; Trade / Commodities, cost of import;

So, the maximum values of Me, Average, ABS (Me-Average demonstrate the priority of interrelations between the Central Bank and the financial corporations via clear requirements to the central government. In this case the growth rates of import cost are the defining indicators of these interrelations.

Cluster analysis of connectivity of growth rates of the Central Bank, financial corporations and trade revealed the strongest relations: (1) Central Bank / Monetary base and Financial corporations / Currency outside financial corporations; (2) Central bank / Requirements to other deposit corporations and Financial corporations / Internal claims.

So, the Central Bank and financial corporations lock interrelations using monetary and credit and currency policy regulating the money supply volume in the context of currency outside financial corporations and internal claims.

Thus the Russian finance capital components movement analysis revealed speculative behavior of the finance capital owners in relation to domestic and external market. It is aided by the state priority in GDP regulation (inflation targeting) in the context of growth of state expenditures and importance of commodities and services import. In this instance the options for export of commodities and services are insignificant and comparable to such countries as Australia, Estonia and Columbia.

In these conditions there grow stronger the interrelations between the Central Bank and financial corporations in the context of clear requirements to the central government. The Central Bank and financial corporations lock interrelations using monetary and credit and currency policy regulating the money supply volume in the context of currency outside financial corporations and internal claims. In this case the growth rates of import cost are the defining indicators of these interrelations.

Russian finance capital components movement analysis result show corporate strengthening of interrelations between the Central Bank and financial corporations in the context of clear requirements to the central government and inflation targeting policy.

So, movement of the Russian finance capital components reflecting strengthening of interrelations between the Central Bank and financial corporations in the context of clear requirements to the central government is radically different from the reasonable actions of the leading countries of the world aimed at achievement of the Sustainable Development Goals (SDGs) of the United Nations.

\section{Conclusions}

Research of the Russian finance capital components movement revealed corporate strengthening of interrelations between the Central Bank and financial corporations in the context of clear requirements to the central government. This allows the Central Bank and the financial corporations to determine speculative behavior of finance capital owners regulating: (1) monetary supply volume in the context of currency outside financial corporations and internal claims; (2) GDP deflator (inflation targeting) taking into account growth of state expenditures and the importance of commodities and services import.

For development of the Russian economy it is necessary to ensure reasonable movement of the Russian finance capital components movement at the gross accumulated fixed capital level. 


\section{References}

1. I. Oino, Research in International Business and Finance 44, 309 (2018)

2. M. Ali, A. Iness, Journal of International Financial Markets, Institutions and Money 69, 101254 (2020)

3. H. Yang, F. Shi, J. Wang, Z. Jing, International Review of Economics \& Finance 59, 120 (2019)

4. R. Mercado Jr., S. Noviantie, Journal of International Financial Markets, Institutions and Money 69, 101255 (2020)

5. E. Brancaccio, R. Giammetti, M. Lopreite, M. Puliga, Structural Change and Economic Dynamics, 45, 94 (2018)

6. K. P. Gallagher, Y. Tian, Review of Development Finance 7(2), 95 (2017)

7. M. Rubio, F. Yao, International Review of Economics \& Finance 67, 378 (2020)

8. R. Matousek, E. Panopoulou, A. Papachristopoulou, Journal of Corporate Finance 62, 101558 (2020)

9. K. Kosmidou, D. Kousenidis, A. Ladas, C. Negkakis, Journal of Economic Behavior \& Organization, 175, 86 (2020)

10. H. Ai, K. Li, F. Yang, Journal of Financial Economics 138(3), 663 (2020)

11. A. Ripamonti, The Quarterly Review of Economics and Finance 77, 75 (2020)

12. Z. Feinstein, European Journal of Operational Research 281(2), 449 (2020)

13. B.-U. Chong, H. Kim, Finance Research Letters 30, 318 (2019)

14. S. Dhole, S. Mishra, A. M. Pal, Pacific-Basin Finance Journal 58, 101212 (2019)

15. D. Zhang, Research in International Business and Finance 55, 101317 (2021)

16. C. Lambrinoudakis, G. Skiadopoulos, K. Gkionis, Journal of Banking \& Finance 104, 1 (2019)

17. O. Merrouche, E. Nier, Journal of International Money and Finance 77, 117 (2017)

18. R. Pancrazi, H.D. Seoane, M. Vukotic, Economics Letters 149, 86 (2016)

19. O. Valencia, D. Osorio, P. Garay, EnsayossobrePolíticaEconómica 35(84), 203 (2017)

20. C. Bui, H. Scheule, E. Wu, Journal of Financial Stability 33, 23 (2017)

21. V. V. Smirnov, V. L. Semenov, E. N. Kadyshev, T. V. Talanova, A. N. Zakharova, N. G. Gubanova, Proceedings of the 35th International Business Information Management Association Conference (IBIMA), 3736 (2020)

22. V.V. Smirnov, D.G. Osipov, A.A. Babaeva, E.V. Grigorieva, E.F. Perfilova, Advances in Economics, Business and Management Research. Proceedings of the 1st International Scientific Conference (2019)

23. V. V. Smirnov, A. N. Zakharova, T. V. Talanova, A. G. Abramova, S. A. Petunova, I. B. Getskina, M. N. Yaklashkin, Proceedings of the 35th International Business Information Management Association Conference (IBIMA), 7741 (2020) 